\title{
US-India Nexus \& Chinese Appraisal: Triangular Exertions in Central \& East Asia (Brief Description)
}

\author{
R.D. Nisar \\ Central China Normal University \\ 152, Luoyu Road, Wuhan, Hubei, People's Republic of China, 430079
}

\begin{abstract}
Apart from the past ideological differences, distrust, divergence of the interests, US and India relationships has been transformed from the estrangement to partnership and at least into potent nexus with the awake of the twenty first century. Since the threshold of the century, Asia is the central part of the world politics where several regional and extraregional actors are trying to secure their interests and want to maintain their hegemony. Apart from India, China and Japan, the US and Russia are the powerful players in the Asian political theatre. After the collapse of the USSR, India and China have emerged as strong regional powers and they are playing their imperative role in the Asian affairs. Fast growth of Chinese economics, arms modernization, advancement in the technology and its course of actions in Asian region and in the sea lane of transportation push the US leadership to reshape its security policies and choose new alliance by adoption of alliance making theory in the context of balance of power in the Asia to secure its position in the region and balance or counter rising threats. Besides this, due to Indian democratic values, rising power, strategical position near the Indian Ocean, nuclear potential and power to contain China, Delhi is perceived in Washington as a valuable ally. The 'India VS China' in the context of economic race, past rivalry, and border issues and 'The US VS China' indicate that the US takes India as a countervail power to balance China in Asian periphery and wants balance of power. According to Chinese political analysts, the aim behind the ongoing US-India juxtaposition is to counter the rising China. This article tries to answer the following questions: "What is the crucial factor behind the inauguration of current US-India Nexus and specially in East and Central Asia?", "What is the general perception of China regarding US-India nexus?", "And what is the course of actions of three powers in Central and East Asia to preserve their positions and interests in respective regions?".
\end{abstract}

Keywords: US-India Nexus, Chinese perception, US-India \& China, Central \& East Asia

\section{Introduction}

After the almost fifty years of estrange relations between two democracies India and the US, both countries decide to reshape their relations in the ending decade of $20^{\text {th }}$ century from estrangement to engagement. Due to the divergence of

(C) Nisar R.D., 2019.

(c) (i) This work is licensed under a Creative Commons Attribution 4.0 International License https://creativecommons.org/licenses/by/4.0/ 
the interests, different policies, ideological differences and the complex blocks system of the US and the USSR during Cold War, the relations between India and the US were not admirable. But, after the breakdown of USSR in 1991, the Indian democratic approach, rising economy, largest population and the Chinese rapid development in the context of modernization in technology, economic growth and its strong appearance as rising power in Asian affairs have changed the Asian strategic environment. The Indian strategic location near the Indian Ocean and growing power to balance the rising China brought close two democracies in contemporary era. Now, apart from the past divergence, the US and India has strategic nexus with mutual values, shared goals and aim to counter or balance China in Asia. Some analysts said that Rising China is the key element between the inauguration of development of the strategic relations between two countries with the awake of $21^{\text {st }}$ century. The US Asian centric approach focuses to build up the alliance with India and others and counter rising revisionist power like China and past rival Russia [1]. The reason is that states watch their interests carefully and can sacrifice other interests whether they are friend or enemy. There is famous proverb to describe the diverse nature of international relations: "There is no permanent friend or permanent enemy in international relations, permanent is only interests. Today's friend may be the enemy of tomorrow and today's enemy may be the friend of tomorrow" [2]. Due to above mentioned statement; the rising China is crucial factor behind the inauguration of the new chapter of relationships between two democracies with the threshold of contemporary century. The current US primary interests in Asia are to promote peace as well as stability and creating balance of power in region and prevent region from dominated by any power as well as group of powers. In the perspective of balance of power, the realistic analysts believe that China's rise will recorder regional politics and Europe will exit in Asia [3]. Therefore, the US as well as the New Delhi leaderships take China as threat to peace and stability in Asian region and want Balance of power in Asia. According to some political pundits, the US high headships takes China as like the USSR in Cold War era and declare the Rising China foremost threat to balance of power in Asia. There are many reliable and credible strategies to counter or balance the threat and most authentic are internal balancing and alliance making theory in the context of balance of power. The internal balancing strategy in balance of power is to build up arms which could also be adopted by threatened states against the rival rising powers to balance it with countervailing capabilities. Reaching military alliances, procurement from outside sources and building up arms through internal production is the key means by which states balance one another. After adopt self-reliance balancing strategy, the threatened states build up their weapon and obtain countervailing capabilities and counter their external threat as well as balance the rising powers which can threat to their national security [4].

In internal balancing strategy, states use to balance each other by building up arms itself or by using internal production. To secure national integrity, the two nuclear rival states of South Asia region Pakistan and India are trying to adopt internal balancing as a first strategy, but with partial resources, lack of technology, forced the both states to depend on exterior factors to improve and secure their 
selves. For example, China adopted the internal balancing and it would be successful due to large size of territory, population, military modernization, new technology, rising economy, nuclear capabilities and can become great threat to other powers including weak or super powers, and securing its national security, dignity, solidarity without depending on external powers. The other strategy in balance of power to create balance in two states is alliance making theory. In which the powerful state make alliance with weak state to make equilibrium between two rival states. For example, since independence, the newly born state of Pakistan was suffered its security threat from India and curb this threat Pakistan was joined the US bloc singing SEATO, CENTO which was sponsored by the US and now the India again join the US bloc against mighty China. As a superpower, the US is adopted alliance makes theory to create balance of power in Asia [4]. Because the rival of the US during the Cold War; Russia has great influence in Asia and China is the upcoming most listed threat for the US hegemony in the world and Asia as well. Another rising Asian power, the democratic India got top priority in the US policy after 50 years and showed its effective participation in Asian affairs after becoming a natural ally or reliable partner of the US. In the military powers rivalry and changing security environment in Asia, the US has focused on alliance making to secure its interests [5]. The challenges include insecurity, instability and inequality in Asia which include nuclear dilemma of North Korea, rising China and Russia and nuclear race in South Asia. The US-Japan alliance may remain as the foundation stone for American engagement in Asia-Pacific. With the Taiwan, the US also enhanced its bilateral ties and secured its position in region. The US desires to maintain its unipolarity and hegemony all over the world especially in Asian nodes South Asia, central Asia, South East Asia and East Asia and counter its pose threats through alliance making strategy. With the Chinese rapid economic growth and expansion of its armed forces, it becomes a biggest problem for the US and the American policy makers are entirely worrying that How we stop Beijing from its growing expansion and influence in Asian region. According to the US, China might at some point in the coming decades follow the course of Germany in the 1890 s, 1900s and 1930s, or of Japan in the 1910s and 1930s. With these worries, the US shakes hand with India due to its economic, nuclear as well as power to contain China and its strategic connection with vast Indian Ocean [6]. The former secretary of state James Baker once said, "Since $19^{\text {th }}$ century, the basic principle of the US national security was to prevent Asia from dominated by any power or group of powers which challenging the US hegemonic position in Asia. Japan was defeated by the US in 1945, and to hedge China today are both the US course of actions which based on the policy of Great Britain in $19^{\text {th }}$ century, if the US wants to play like British empire did, the US would need to trap other regional powers like Japan, Australia, Russia and India against rising China. Huntington argues that it is possible for the US to contain China, if other Asian powers would really like to balance China in this century [7]. The very numbers of US realists reject the Chinese claim of peaceful rise and they argue that Chinese course of actions, ideologies in every perspective are a threat to American global primacy. According to John Mearsheimer, a very famous American international relations theorist and 
the creator of offensive realism that the ongoing US-India strategic nexus aims to counter Chinese rise and he believes that it is impossible for China to rise peacefully. He also argues that the main aim behind the US relations with India and other Asian powers is to stop the increasing Chinese appearance in Asia. He said China is making effort to push the US out of the Asia-pacific and Chinese leadership is likely to imitate the US and attempt to become a regional power [8]. Mr. Brad Glosserman, the executive director of CSIS argues that China is seeking to replace the US as the dominant power in Asia [9]. The director of the centre on Chinese strategy at the Hudson institute Mr. Michael Pillsbury argues that China is in the process of executing a secret century-long strategy to replace the US at the dominant global hegemon by the year 2049 and the other side US is trying by leaps and bounds to counter this upcoming threat China to its hegemony by making alliance and partnerships with the native Asian countries and the India is top listed country [10]. The editor of National security columnist and the reporter for the Washington times Bill Getz claims that the China is the most serious national security threat the United States faces at present and will remain so into the foreseeable future [11]. Aeron Friedberg claims that China wants regional hegemony and embellishes the crown of Asian regional power, but the US and its potential ally India don't want this scenario. The US has threats regarding the upcoming partnership between the Eurasian powers e.g. Russia-Sino, Sino-India, Russia-Sino-Japan-India etc. Therefore, the US takes India as a natural ally as well as other Asian states to hedge rising China and secure its interest in Asia. In addition, in Indian perspective, Indian followed two dimensions to get its strategic interests, first protect its security and economic as well as energy interests in the region and move beyond the boundaries of South Asia and in the rest of Asia. Besides these ambitions, according to Indian political pundits, China is the biggest challenge to Indian national safety and Indian interests in the region and on the platform of US-India nexus, India will get chance to balance China. According to the Indian foreign secretary named Shyam Saran "China is upsetting the balance of power in Asia and is threat to the peace of the region and India and the US can do their best to counter rising China. According to Indian high officials, New Delhi will be a regional power with the help of this strong nexus with the US and the transfer of the US advance technology, military hardware to India. As a result, India will become one of the great powers of world with the coming decades in the context of Indo-US economic and security nexus" [12]. India shows its efficiency as a balancer in the US alliance making theory strategy, because India wants to get full fledged protection from the US to its security and access to energy resources to rest of the Asia. The ongoing nexus and cooperation of India-US, India-US-Japan, US-South Korea, and India-US-Russia and Indo-US-Israel have significant implications for China and the main theme of these all nexus is that the US wants to maintain its hegemony and unipolarity status in the world, securing its interests in Asia region, and counter its pose future threats like Russia, China, and North Korea. The very most important fact that the India has very significant strategic location which is very near to Indian Ocean and sea lanes of communication, which push the US leadership to reshape its relations with India from estrangement to 
partnership [13]. The US ideologies of exceptionalism, Paternalism, hegemonism and the Indian dream to get crown of the Regional power are also playing as crucial factors behind the formation of new episode of US-India relations. The US success in World War I, World War II, Cold War and inauguration of the liberal world order after the decline of the USSR describe that the US is the exceptional power and according to the Americans, in world, no state has power to challenge the US exceptionalism [14]. The US exceptionalism means that the US is unique, powerful country in the world. The US approach of exceptionalism defines one more concept of Paternalism. Its means that the US is the most powerful country of the world and all the countries of the world need the US help and guidance and without the US, even their survivals are very complicated [15]. Therefore, with the help of these two concepts, the US gives American hegemonism notion and the US not ready to face any decline of its hegemony in the world particularly in Asia. In the $21^{\text {st }}$ century, the world system or structure is not like the structure of past, where two powers the US and the USSR was fighting against each other. Now, there are multipolar world system and the US feel threat from the rising powers. Maybe, in coming future they challenge the US power. Therefore, the US elites plan to establish partnership especially with Asian powers to restore its power in Asian region. The policies of the US leadership from Nixon to current leadership are same to make the US world superpower and hold the US hegemony in the world [16]. Besides this, the Indian dream to get UNSC permanent seat, military modernization, Asian NATO, the Pakistan factor, Pakistan-China nexus, Central Asia energy resources and the rising China are the fact which cannot be underestimated while discuss the US-India nexus. On the platform of this Nexus India wants to secure its interests and make its regional primacy and the US is best option in the hand of the Indian policy makers. In addition, India signed military treaties with US as GSOMIA (2002), LEMOA (2016), COMCASA (2018) and further the Quadrilateral Security Dialogue (QUAD) enhance Indian regional policeman gestures and aimed to counter rising China or Russian re-emergence in Asian region [17].

\section{US-India Nexus and Chinese Views}

Since the day of inauguration, China directly inspects the US-India nexus when the leaders of the two nations signed agreement of 5 July 2005 and examined the past policies of the US leadership, especially Clinton towards India. More significantly, Beijing perceives this nexus as an attempt by both democracies to enlist New Delhi as a potential counterweight adjacent to China. From the beginning of the G. Bush administration, the US takes India as a major political player, emerging economy, its vital role in Asian stability, and has power to balance China in Asian region [18]. Chinese academics firmly believe that the ongoing potent US-India engagement in Asia is a part of the US policy of "dodge" to encircle "the mighty China" in future. The joint military exercises, naval exercises, defense conferences, strategic collaboration among two countries and shift of military weapons and defense technology to India are aimed to balance China's growing power in Asia. The US military hardware's PC Orion maritime reconnaissance 
aircraft and Aegis radar system to India have a China-specific focus [19]. Furthermore, Beijing viewed US-India nexus as part of the US global strategic calculation to enlist India to poise against rising China. China's official media stated about the US military connections with India that "US dreams of Asian NATO". According to the US president Bush at Bucharest NATO summit "now NATO would send its forces across the world for future of freedom and peace of millions". It clearly means that Asian NATO has framed new alliance and Russia and China are its rivals. According to the US policy makers, India has an important strategic position connecting the Indian Ocean and the Pacific Ocean and with the help of their nexus, the US will expand its strategic presence in South Asia and offset the Russian and Chinese strategic position in the region. Chinese leadership said that, the US basic function of closer ties with India and an Asian version of NATO is to expand its hegemony in Asia and securing its interest [7]. In the context of burgeoning US-India nexus, the US maintain as well as make bigger its hegemony and wants to play decisive role in the Asian region and in South Asia predominantly. Liu Jianfei said that "since the twenty century, the main theme of the US strategy in the context of worldwide to maintain its hegemony and counter its enemies or counter China". Beijing believes that China is the only country with rapid economic growth and its defensive capabilities challenged the US global leadership in the Asia and will make a probable competitor in future after the breakdown of USSR [20]. In addition, the US takes China as a future competitor and adopted containment strategies to curtail China in Asian region and sea lanes of communication. In the term of balance of power, Chinese officials accept as true that the US-India nexus would bring a major shift in South Asia and Indian Ocean Region. According to A. Mahan, a great naval analyst, "Whoever controls the Indian Ocean dominates Asia" [21]. With the awake of twenty first century, the destiny of the world will be decided in these waters. Due to Indian preeminent dominant power in the Indian Ocean region, the ongoing US Navy's dominance of the high seas and maritime lanes as well as joint Indo-US military exercise in maritime lanes aim to counter Chinese expanding power in Indian Ocean which give red signal to China. In the case of Indian Ocean, prominent Chinese strategists believe and the editorial in Ming Pao describe that "the US wants to enhance as well as maintain its supremacy in Indian Ocean with its alliance India and Japan with India-US-Japan nexus. On January 29, 2002, the US president Bush enlisted China the top of its rival across the Taiwan straits and in Asia. After the Bush, the leadership of the US, Obama is more friendly and cooperative towards China, observed by political analysts. But this observation is rejected by Evan Feigenbaum, an officer in the Bush administration, who wrote in an article of Foreign Affairs, according to many political experts, the subject of the US policy to secure its hegemony in Asia and counter the rising threats. Mr. Chung Young-June, a Chinese scholar at China foreign affairs university says that the main theme of the US all policies and strategies is "Preserving and maintaining its world leadership position". The professor in the centre for American studies at Fudan University follows the ideas of Young-June and he asserts that the American primacy strategy is focused on "leadership" and "dominance" a dangerous form of hegemony. United 
States of America will do everything to preserve its power and influence and that the US is containing a peacefully rising China because it fears decline [22]. Many Chinese scholars argues that the US is an offensive and hostile power and the ongoing strategic nexus with India aim to watch Cleary the Chinese actions and navel exercises in Indian Ocean. The Chinese admiral once said that the American navy is like a man with a criminal record wandering just outside the gate of a family home. $\mathrm{Lu}$ Yin, an associate research professor writes an article "Building a new China-US strategic stability". In this article he argues that the US is afraid to lose its breaking down uni-polar system. The US wants its power by any means in Asia [23].

\section{Central Asia}

China is emerging as the dominant actor in Central Asia and shares its border with three states, while India and the US also want to create strong presence in the region for energy, trade, and to decrease the influence of China. Thereby, the USIndia nexus will have far-reaching implications for Chinese interest in the Central Asia. After the collapse of USSR, Central Asian states; Uzbekistan, Turkmenistan, Kazakhstan, Kyrgyzstan, and, Tajikistan became independent. The region being rich in energy resources and has attracted global actors, made it more important for China strategic, security, political, and economic interests. In addition, US-India nexus directly and indirectly hit the Chinese interests in Central Asia. India is determined to treat CA as "extended neighbour" and want to get access to rich energy resources. About 13 to 15 billion barrels of oil deposits and 270 to 360 trillion gas deposits have been confirmed in region. Additional to that the actual deposits of oil are 40 to 140 billion barrels. Kazakhstan, Turkmenistan and Uzbekistan are the main natural resources e.g Natural gas and natural oil deposits of the Caspian Sea. All major and regional powers the US, Russia, China and India are trying to get full energy access to boost their energy sector as well as trying to capture the oil and gas resources of region after making good relations with Central Asian states. According to strategic analyst "new great game" is telling to face on strategic competition for transit route. The countries like the US, India, UE, Russia, China, and Pakistan have desire to build huge pipeline to get access to enormous oil and gas resources. Against the Russian transport monopoly, the US and EU transport route towards west through Azerbaijan, Georgia, turkey as well as China is developing pipeline towards the east and India-Pakistan both states desire to get hydrocarbon resources to draw them southwards. So pipeline politics has led to rivalries in region for influence. The strategic competition among the major power global players, the US, China, Russia and India has intensified in the last few years [24]. The US grew its influence in Central Asia after Cold War and after 9/11 incident. The main objective was only to spoil Russian military doctrine of "Near Abroad" and counter its future threat of expanding China in Central Asia. After the terrorist attack of 9/11, the war on terror provided opportunity to the US to strengthen military appearance in Central Asia thus it built air bases in Kazakhstan, Kyrgyzstan, Uzbekistan and Tajikistan. The "regional energy grid" idea is supported by the US to transport gas and electricity from Central Asia to South Asia 
and World Bank, International Monetary Fund (IMF) are offering funds for this project. In addition, India and the US shares interests in counter terrorism in region it means that the US wants to cooperate with India in Central Asia region to secure their interests and access to natural resources of the region. According to Indian scholar Gulshan said that "In the coming future, India will balance its rising threat China in Central Asia". Indian policy makers believe that region is important for India because its strategic location and Tajikistan is only 20 kilometres away from great Kashmir and developing close relations with Central Asia. India approved $\$ 5$ billion to participate in TAPI gas pipeline. India has extended its military contacts with Central Asia and setup military base in Tajikistan and its first Indian military setup in foreign land to secure its energy interest in Central Asia. Defence minister of India stated that India made an immediate plan to deploy MI-17 helicopter in Central Asia and trains Tajik pilots. The establishment of air base gave India an opportunity to increase its influence in region and counter China completely. China is closely watching the activities which are above mentioned and carried by the US and India very sharply and to counter to their anti-Chinese policies in the Central Asia, it developed close bilateral relations with CARs in the field of politics, economic, and strategic. China invests in oil and gas industry and energy supplies through pipeline [24]. The Kazaks have also built an oil pipeline that links Kekiyak in Kazakhstan to Xinjiang province in China. The organization Shanghai Cooperation Organization (SCO) grew out of Shanghai five that was formed in 1996. SCO was set up with major six countries China, Russia, and four Central Asian states Kazakhstan, Kyrgyzstan, Tajikistan and Uzbekistan in 2001. Basically, the organization was aimed to build security, trade, military, political cooperation among member states. China shares 14,799 km border lines with SCO member's states. It started from functional issue like demarcation of Sino-Russian border. SCO has focused on close economic relations among member states; it means to facilitate free flow of commodities, technology in the region externally but internally decrease the influence of India and the US from the region. SCO focused on fighting against terrorism, extremism, for regional peace, stability and prosperity. China is participating in anti-terrorism military exercise among the SCO members [24]. In 2004, SCO was established Regional Anti-Terrorism Structures (RATS) to coordinate SCO members and the "Peace mission 2007" was held by SCO. Chinese ambassador in Russia said that "SCO aims to cooperate among member states, we have no aim to build a military bloc with security, mutual trust, benefit, and equality would be advocated by SCO in future." According to the US senior officials, the SCO is the club of Central Asian states which is founded and lead by China to aim to get its interests as well as access to natural resources in the region and its periphery. In addition, to counter Indian "Look East Policy" and the US policies and activities in the region after making the Central Asian states its strategic and economic partners. The US perceives that SCO plays directly and hit its interests in region, because the US is not member of SCO and decrease the influence of Indo-US nexus in Central Asia. The Chinese General Liu Yazhou of China's People's Liberation Army said that "Central Asia is the thickest piece of cake given to the modern Chinese by the heavens". The success behind the Chinese 
ongoing OBOR initiative policy and new Silk Road Plan need regional powers alignments and cooperation. Geopolitics is be like a chess game of many different levels and it's not easy to win but with clever grand visions and course of actions. The major and regional powers the US, Russia, China and India are trying their best to increase their influence in this region [25].

\section{East Asia}

East Asia including South East Asia is also another important strategic and economic periphery region for China. East Asia is union of South East Asia and North East Asia. In the context of Chinese energy security, maritime security, economic and trade development region is very important. China is a big power in East Asia and promotes regional peace, prosperity and stability. The region holds very important position in the global and regional interests of the US. China has very significant economic, political and strategic interests in the region which are associated with the 1990s China's "new security concept" [13]. Mr. Wu Baiyi, the China Foundation for International and Strategic Studies, said that "compared to past policies, the concept signifies two major changes... For the first time, economic security is treated as equally important with those of "high politics." Second, it "focuses more on the interrelationship between external and internal security in the region" [26]. Against this broad perspective, China attaches great importance to its economic interests in the region as it considers itself a regional economic power. The main challenge for China is to convince the regional countries that "China is an economic opportunity for them and not a threat... the worst case for China is that ASEAN members extend their fears of Chinese economic growth to an allround apprehension of China [27]. To pursue this interest China wants to present itself as the biggest market, and source of investment to make China the engine of economic growth in the region. China has strong strategic interests in the region which has heavy concentration of major powers, including the US, Japan, Russia, India and China itself. The "primary aim of the Chinese regional security is thus to avoid the formation of coalition of regional countries against the rise of China. Within this context China attaches great significance to the small and medium powers such as the two Koreas in Northeast Asia and ASEAN members in SouthEast Asia for Chinese security environment. Politically, China wants to increase its clout in the region. It desires recognition and appreciation as a regional power. A Chinese analyst, Zhang Tiejun, observes: The best way to achieve so is thus to promote China's image as a responsible regional power" [28]. In the context of USIndia nexus both countries have economic and strategic interests in the East Asian region. The US deputy secretary of state John D. Negroponte was talking on the US Policy in Asia: Meeting Opportunities and Challenges, at Brookings Institution on 28 July 2008, noted that to meet the opportunities and challenges posed by “Asia's extra-ordinary rise", US was shaping its policy. He argued that the US is basically pacific power and want a Balance of power in region. Further he said that "our alliance with Japan, South Korea, Australia, Philippines, Thailand and India remain the foundation of peace and security in Asia and the US modernize its alliance in 
North East Asia for the realities of $21^{\text {st }}$ century". The US also has strengthened cooperation with South Korea for regional peace in Asia. In addition, the US had reached out to new friends in South East Asia like Indonesia and Vietnam. The US had entered into a strategic nexus with India that is against the broader perspective and relationship between the US and India has a lot of impact on Chinese interests in the region. The US and India, both countries have common interests in East Asia region [1]. The US is the dominant power in Asia pacific region and India pursing its "look East" policy, which was framed in 1990, makes India more careful about its interest in region. The "Look east" policy of India is also a sign of its desire for status of global power which will be possible only to build its close political and economic relations with the US. India is soft ally of the US in its counter terrorism in region as well as maritime security, especially the safety of Malacca Straits and increases its oil imports through straits. According to China, this counter terrorism and maritime security is the part of "East Look" policy to decrease Chinese influence in East Asia region and further control Indian Ocean. The maritime cooperation between India and Japan is to counter growing China maritime clouds in Asia. According to Indian Navy, Chinese "String of pearls" strategy enhances its military profile in Indian Ocean. According to Indian Naval chief Arun Prakash, "India is in the middle of Indian Ocean and that is where China has implemented its "Strings of pearl" strategy. China will implement its strategy around us as "weapon client states" like Bangladesh, Myanmar, Sri Lanka, Saudi Arabia, Iran and Pakistan. Furthermore, the US has same perceptions about China naval strategy. In addition, India wants to deploy its force around the straits of Malacca in Bay of Bengal. India has naval command has 50 naval ships, 55 aircraft carriers, submarine, naval sea fighters and helicopters. It means that Indo-US nexus would encourage competition between China and India in straits of Malacca and region. To explain the Chinese "new security concept", famous Chinese analyst Wu Baiji said that "compared to past policies, the current concept is based on two shapes, economic security and interrelationship between external and internal security [29]. To follow this concept, China wants to present itself as biggest market and attract investors for investment. The basic aim of China regional security is to avoid the formation of alliance of regional counter against China. China dependence on ship borne energy supplies are growing thereby straits are gaining importance in its energy security. At present, China's 69\% oil is transported through strategic sea lanes. Though the safely of straits narrow stretches of waterway between Malaysia and Indonesian island of Sumatra become very important for China. Malacca straits are observed by Chinese scholars that safety of Sea Lanes of communication (SLOC) may trigger maritime conflicts. While safety of Malacca straits is in the interest of all major powers. An exclusively control of security by the US and its alliances such as Japan, India, Australia and Indonesia would not be desirable for China. Moreover, the possibility of war of Taiwan Strait would be fought between China and the US. The US navy has the naval base in Indian Ocean and $80 \%$ Chinese oil tankers go through this dangerous line under $100 \%$ the US control [29]. Due to this Beijing forced itself to frame lane base energy transportation routes. The Andaman Sea, US-Australia-Japan-India did war game which raised eyebrows 
in Beijing. After 9/11, the US framed its new alliance such as Japan, South Korea, Indonesia, Philippines and but bad turn have taken place in Sino-Japan relations. The other maritime issues like terrorism, human trafficking on Malacca straits would be common interests where China would not feel threat. The small states like Malaysia and Indonesia are not willing to increase the US and Indian influence in Straits of Malacca and region. They prefer China because China has cooperative security strategy and also member of ASEAN and ARF. China increases its economic relations with ASEAN countries and provides them a big market and enhances its range in region. In this context, sea lanes security is added in Chinese maritime strategy [13].

\section{Conclusion}

US-India nexus is a part of reshaping of the US Asian policy from Bush Doctrine to Indo-Pacific which geared to protect the US interests in $21^{\text {st }}$ century. The ongoing US-Indian juxtaposition has great global implications for China, especially in terms of relations with the US and Russia. Some countries perceive this nexus best for peace of world that two democracies joined hand with gorgeous responsibilities like non-proliferation, counter-terrorism, peace and stability, and economic sphere. Other hands, some countries believe that the this nexus is pictogram of instability in Asia, because the transfer of the US advanced technology in the context of military, nuclear and defence to India make it able to play its crucial role in Asia as well as this Indian maturity is serious security threat for other states like China and Pakistan and small states of South Asia. Furthermore, Indian shows its efficiency after making natural ally of the US but on the other hand many wellknown Indians think tanks assert that India could become just a puppet in the hands of the US and take this nexus only in the context of American interests. According to them, the primary interests of the US in Asia are to contain rising China, decrease the influence of China in Asian region, access to Vast Indian Ocean sphere and access to natural resources. They believe that the US-India collaboration in economic, political, strategic, military and defence areas are only in the favour of the US and the basic theme of this collaboration is to just make India able to counter China, secure its interests and nothing else. They said that the India must learn a lesson from the US dual role during the Cold War and never trust on the US with blind eyes. On the contrary, other school of thoughts is in the favour of this potent nexus of two democracies. According to them, India is raising economic power with huge territory, population and resources and the China is the only country in Asia which hit the Indian desires in Asia. Besides this, the dreams of permanent seat in United Nations Security Council (UNSC), leader of Asian NATO, arms advancements, progressive aircrafts and technology are also associated with this nexus. So, apart from all divergence with the US and knows very well about the dual policy of the US, India's first priority is to counter rising China in the rest of Asia and Indian Ocean periphery and secure its Interests. In the case of China, some Chinese perceive that the US-India nexus is not immediate threat for China. And they are busy to gain its goals which are formulated after its independence in 1949. On the other hand, majority of the Chinese believe that the basic theme of this strong 
nexus is only to encircle China. The US policies Bush Doctrine, Pivot to Asia and Indo-Pacific aimed to encircle the mighty China and preserve its hegemony and title of King of uni-polar world under the ideologies of exceptionalism, paternalism and hegemonism. By making alliance in the Asian region, the US is repeating the history like the Cold War and defeat the USSR. Being the active player and stakeholder of Asia, the Chinese leadership believes that the rising China has soft power and harmonies world approach. They assert that China is not threat for the world and Asia and wants peace in the world and is playing crucial friendly role in Asian and world affairs. China has very soft power approach towards its neighbours and globe and its OBOR policy is also for the progress of the world. At the end, apart from all other regional powers, the US, China and India, all three countries have very complex triangular relationships and they should follow the approach of friendly and cordially relations rather than being hostile to each others, because the rivalry between them leads to serious war and create instability in the rest of the world and eliminate the world as well as regional peace. So, for the world peace and prosperity and being the vigorous geo-political players of Asia, these three states should eliminate their divert ideas and conceptions and create a valuable relationship among them. They should enhance economic, trade, political relations; people-to-people contact and prevent Asia from being dominated by any single power and make efforts to demolish terrorism and instability from the Asia.

\section{REFERENCES}

[1] Hosli M.O. The United Nations Security Council: History, Current Composition, and Reform Proposals. The Changing Global Order: Challenges and Prospects. Springer Nature; 2020: 299-320.

[2] Waltz K. Neorealism: Confusions and Criticisms. Journal of Politics and Society. 2004; 15 (1): 2-6.

[3] Sieff M. Shifting Superpowers: The New and Emerging Relationship between that United States, China, and India. Washington: Cato Institute; 2009.

[4] Naseer R., Amin M. Balance of Power: A Theoretical Explanation and Its Relevance in Contemporary Era. Berkeley Journal of Social Sciences. 2011; 1 (10): 5.

[5] Sharma S.D. China and India in the Age of Globalization. Cambridge: Cambridge University Press; 2009.

[6] Little R. The Balance of Power in International Relations: Metaphors, Myths and Models. Cambridge: Cambridge University Press; 2007.

[7] Craig S.L. Chinese Perceptions of Traditional and Nontraditional Security Threats. Carlisle: Strategic Studies Inst.; 2007.

[8] Mearsheimer J.J. The Gathering Storm: China's Challenge to US Power in Asia. The Chinese Journal of International Politics. 2010; 3: 381-396.

[9] Glosserman B. A "New Type of Great Power Relations"? Hardly. Pacific Forum CSIS; 2013.

[10] Pillsbury M. The Hundred-Year Marathon: China's Secret Strategy to Replace America as the Global Superpower. Henry Holt and Company; 2015.

[11] Gertz B. The China Threat: How the People's Republic Targets America. Washington: Regnery Publishing; 2000.

[12] Garrett B. US-China Relations in the Era of Globalization and Terror: A Framework for Analysis. Journal of Contemporary China. 2006; 15 (48): 389-415.

[13] Tellis A.J., Mirski S. Crux of Asia: China, India, and the Emerging Global Order. Washington: Carnegie Endowment for International Peace; 2013. 
[14] McCoy T. How Joseph Stalin Invented 'American Exceptionalism'. The Atlantic. 2012: 3 (15). URL: https://www.theatlantic.com/politics/archive/2012/03/how-joseph-stalininvented-american-exceptionalism/254534/. Accessed: 05.02.2020.

[15] Walt S.M. The Myth of American Exceptionalism. Foreign Policy. 2011. URL: https://foreignpolicy.com/2011/10/11/the-myth-of-american-exceptionalism/. Accessed: 06.02.2020.

[16] Shambaugh D. Tangled Titans: The United States and China. Lanham: Rowman \& Littlefield Publishers; 2012.

[17] Zishra K. Indo-US Strategic Relations Set to Strengthen. Asia Times. URL: https://asiatimes.com/2019/03/indo-us-strategic-relations-set-to-strengthen/. Accessed: 04.02.2020.

[18] Ghoshal B. China's Perception of India's' Look East Policy' and Its Implications. Delhi: Institute for Defence Studies \& Analyses; 2013.

[19] Jabeen M., Ahmed I. Indo-US Nuclear Cooperation. Journal of Contemporary Studies. 2014; 3 (1): 18.

[20] Guihong Z. US-India Security Relations: Implications for China. Delhi: FaultlinesNew Delhi; 2003: 29-48.

[21] Zhang G. US-India Strategic Cooperation: Implications for China and Pakistan. International Studies. 2005; 42 (3-4): 277-293.

[22] Dent C.M. (Ed.). China, Japan and Regional Leadership in East Asia. Cheltenham: Edward Elgar Publishing; 2010.

[23] Yin L. Building a New China-US Strategic Stability. Contemporary International Relations. 2012; 22 (6): 80-97.

[24] Akhter S. Indo-US Strategic Partnership: Implications for China. Regional Studies. 2009; 27 (1): 3-80.

[25] Pantucci R. China Must Get Along with Regional Powers to Make Its New Silk Road Plan Work. South China Morning Post. 19.08.2017. URL: https://www.scmp.com/ comment/insight-opinion/article/2107122/china-must-get-along-regional-powersmake-its-new-silk-road. Accessed: 10.02.2020.

[26] Baiyi W. The Chinese Security Concept and Its Historical Evolution. Journal of Contemporary China. 2001; 10 (27): 275-283.

[27] Asher M.G., Sen R. India-East Asia Integration: A Win-Win for Asia. Economic and Political Weekly. 2005; 40 (36): 3932-3940.

[28] Dadwal S.R. China's Search for Energy Security: Emerging Dilemmas. Strategic Analysis. 2007: 31 (6): 889-914.

[29] Zhang G. US-India Strategic Cooperation: Implications for China and Pakistan. Pakistan-China Relations in Changing Regional and Global Scenario. Karachi: Area study center; 2005.

Научная статья

\title{
Внешнеполитические связи между США и Индией и их оценка Китаем: проблема напряженности в трехсторонних отношениях в Центральной и Восточной Азии (краткое описание)
}

\author{
Р.Д. Нисар \\ Классический университет центрального Китая \\ № 152, Люою Роад, Ухань, Хубэй, КНР, 430079
}

Аннотация. Несмотря на историю прошлых идеологических разногласий, недоверия и расхождения интересов, к началу XXI века отношения между США и Индией пришли от отчуждения к партнерству или, по крайней мере, к масштабной взаимосвязи. 
Сегодня Азия находится в центре мировой политики, и несколько региональных и внерегиональных игроков пытаются защитить свои интересы и сохранить свою гегемонию. Помимо Индии, Китая и Японии, США и Россия являются влиятельными игроками на азиатском политическом театре. После распада СССР Индия и Китай заняли позицию сильных региональных держав, играющих свою важную роль в Азии. Быстрый экономический рост Китая, модернизация армии, развитие технологий и выбранный последовательный внешнеполитический курс в регионе и на морских транспортных путях подталкивают руководство США к изменению своей политики безопасности и созданию альянса в контексте баланса сил в Азии, для того, чтобы укрепить свои позиции в регионе и противостоять растущим угрозам. Кроме того, развитие в Индии демократических ценностей, ее растущая мощь в Индийском океане, ядерный потенциал и возможность сдерживания Китая сблизили две демократии. Внешнеполитические векторы «Индия против Китая» в контексте экономической гонки, соперничества в прошлом и пограничных проблем, а также «США против Китая» указывают на то, что США воспринимают Индию как «компенсирующую силу», способную сдерживать Китай на периферии Азии и добиваются формирования соответствующего баланса сил. По мнению китайских политических аналитиков, цель продолжающегося сближения США и Индии заключается в противодействии растущему Китаю. В данной статье автор попытается ответить на следующие вопросы: «Что является решающим фактором для появления нынешней связи между США и Индией, особенно в Восточной и Центральной Азии?», «Каково общее восприятие Китаем этой связи?», а также, «Каковы действия трех держав в Центральной и Восточной Азии по сохранению своих позиций и интересов в соответствующих регионах?».

Ключевые слова: альянс между США и Индией, отношение Китая, США, Индия, Китай, Центральная и Восточная Азия

\section{Информация об авторе:}

Рана Даниш Нисар - аспирант Школы политики и международных исследований Классического университета центрального Китая (KHP) (ORCID ID: 0000-0002-13545144) (e-mail: ranadanishnisar@gmail.com).

\section{Information about the author:}

Rana Danish Nisar - PhD Scholar of the School of Politics and International Studies, Central China Normal University (People's Republic of China) (ORCID ID: 0000-0002-13545144) (e-mail: ranadanishnisar@gmail.com).

\section{Для цитирования:}

Nisar R.D. US-India Nexus \& Chinese Appraisal: Triangular Exertions in Central \& East Asia (Brief Description) // Вестник Российского университета дружбы народов. Серия: Государственное и муниципальное управление. 2020. Т. 7. № 2. С. 141-154. DOI: 10.22363/2312-8313-2020-7-2-141-154

\section{For citation:}

Nisar R.D. US-India Nexus \& Chinese Appraisal: Triangular Exertions in Central \& East Asia (Brief Description). RUDN Journal of Public Administration. 2020; 7 (2): 141-154. DOI: 10.22363/2312-8313-2020-7-2-141-154 